\section{Students' Behavioral Intentions Regarding the Future Use of Quantitative Research Methods}

\author{
Polona Tominc \\ University of Maribor, Faculty of Economics and Business, Slovenia \\ polona.tominc@um.si
}

\section{Maruša Krajnc}

Master student at the University of Maribor, Faculty of Economics and

Business, Slovenia

marusa1993@gmail.com

\section{Klavdija Vivod}

Master student at the University of Maribor, Faculty of Economics and

Business, Slovenia

klavdija.vivod@student.um.si

\section{Monty L. Lynn}

Abilene Christian University, College of Business Administration, Abilene, Texas, USA

lynnm@acu.edu

\section{Blaž Frešer}

University of Maribor, Faculty of Economics and Business, Slovenia

blaz.freser1@um.si

\begin{abstract}
Changes regarding the importance of graduates' competences by employers and changes of competences themselves are to a great extend driven by the technological changes, digitalization, and big data. Among these competences, the ability to perform business and data analytics, based on statistical thinking and data mining, is becoming extremely important. In this paper, we study the relationships among several constructs that are related to attitudes of economics and business students regarding quantitative statistical methods and to students' intention to use them in the future. Findings of our research provide important insights for practitioners, educators, lecturers, and curricular management teams.
\end{abstract}

Keywords: students' behavioral intentions, quantitative statistical methods

\section{Introduction}

The global changes, characterized by the digitalization of everyday life, the use of mobile devices, and the characteristics of the fourth industrial revolution, are also changing the competences that are demanded by employers when hiring new employees (World Economic Forum, 2016). The consequence of these changes
ORIGINAL SCIENTIFIC PAPER

RECEIVED: FEBRUARY 2018

REVISED: APRIL 2018

ACCEPTED: APRIL 2018

DOI: 10.2478/ngoe-2018-0009

UDK: 311.21:378:37.063

JEL: A23, COO

Citation: Tominc, P., Krajnc, M., Vivod, K., Lynn, M. L., \& Frešer, B. (2018). Students' Behavioral Intentions Regarding the Future Use of Quantitative Research Methods. Naše gospodarstvo/Our Economy, 64(2), 25-33. DOI: 10.2478/ ngoe-2018-0009

\section{NG OE}

NAŠE GOSPODARSTVO OUR ECONOMY

\begin{tabular}{l|l|l} 
Vol. 64 & No. 2 & 2018
\end{tabular}

pp. $25-33$ 
is the high velocity, high volume, and high variety of big information assets (known as "big data") that demand cost-effective, innovative forms of information processing for enhanced insight and decision-making. In these changed circumstances, businesses today are seeking new and better ways to remain competitive, profitable, and prepared for the future; for achieving this, companies are aware of the importance of information hidden in the big data. Thus, it is not surprising that, among top competences that are the most important for employers, according to different authors, the statistical analysis and data mining ability, along with data visualization, are found within top-10 places (LinkedIn, 2016, 2018; World Economic Forum, 2018).

Our research stems from the fact that, nowadays, management in enterprises is faced with the amount of data, growing at a rapid rate, i.e., the analysis of insights of data must be used with the purpose to lead to better decisions and strategic business activities, if companies want to adapt to rapid and constant market changes. Managers in companies are often lacking detailed knowledge and understanding of data and business analytics skills, and their application in strategic and operational decision-making, which is associated with advanced statistical methods by using statistical software support.

Among the important characteristics of efficient educational institution and its study programs is the ability to continuously (re)design study programs' learning outcomes according to the demands of the labor market: moreover, higher educational institutions must have the ability to anticipate, which are going to be competences of graduates, that companies will be looking for at their future employees. The above-mentioned competence of data and business analytics skills is in the forefront of these efforts.

The aim of our paper is to shed light on the development of the ability (competence) to perform quantitative research by students. Quantitative research is to a great extent associated with statistics; statistics contents are usually included in the quantitative courses of study programs, regardless of the study cycle and the field, thus expressing the growing importance of statistical knowledge in natural, social, and physical sciences. On the other hand, students at different levels are facing difficulties in learning statistics and quantitative methods in general; it was found that students see statistics and quantitative topics in general as being more difficult than other domains, with negative attitudes often being the main obstacle (Murtonen \& Lehtinen, 2010). Several studies have shown the relationship between students' attitudes toward quantitative methods and their performance as well (Mondejar-Jimenez \& Vargas-Vargas, 2010; Murtonen \& Lehtinen, 2010). Another characteristics of the quantitative courses including statistics is that, at least for last 20 years, the use of statistical software support is included (Biehler, 1997; Bovas, 2007). The technological development had a real impact on the statistics discipline in general and on the training of professional statisticians and users of statistics in particular.

Our research model is based on the previous researches' results utilizing the technology acceptance model (TAM) (Davis, 1986) with included external variables to the model, which were proven to be important (Šebjan \& Tominc, 2015; Marjanovič Umek et al., 2004; Hsu et al., 2009; Macher et al., 2012; Krueger et al., 1993; Yousafzai et al., 2007; Linan \& Alain, 2015). The main goal of our research is to test if the external factors analyzed are associated with students' perceived ease of use of quantitative methods and students' perceived usefulness of them. We assume that perceived ease of use and perceived usefulness of quantitative methods are related to the attitudes of students toward quantitative methods and their behavioral intention to use these methods in the future. Our research is not aimed at testing the TAM model but is limited to the analysis of relationships among variables of the research model, presented in the paper.

Research is based on a survey among master's degree students in economics and business who had the course of quantitative methods in their study program. The random sample was obtained with the purpose to test hypotheses formed. Multidimensional variables/constructs were formed by factor analysis. Pearson correlation coefficients were used to test the significance of relationship among constructs.

The paper is structured as follows. After the introduction, the literature review is presented. After methodology and data section, results and conclusion with discussion are presented. A plan for further research is offered as well.

\section{Theoretical Background}

\section{Model TAM}

The TAM is one of the most frequently used models for researching the usefulness of technology, program supports, and information solutions. The work of Davis (1986) may be viewed as the beginning of the development of TAM. It is based on the theory of reasoned action (TRA) (Fishbein \& Ajzen, 1975), which is built on the belief-attitude-intention-behavior relationship. This model has been further developed using the theory of planned behavior (TPB) from social psychology (Ajzen, 1991). According to this theory, behavioral intentions indicate a person's intention to carry out the specific behavior. 
According to the TPB, individual's behavioral intentions are shaped by the three antecedents: attitude toward the behavior, subjective norm, and perceived behavioral control. Beliefs, attitudes, and intentions are also important factors in the adoption of computer technologies (Bagozi et al., 1998). TAM has been successfully used in the past to study different aspects of students' acceptance of technology (Sabalic \& Schoener, 2017) of information communication technologies (Ali et al., 2016; Abdulah et al., 2016) and software acceptance (Antonius et al., 2015; Šebjan \& Tominc, 2015; Brezavšček et al., 2017), etc.

Venkatesh and Davis (1996) summarize TAM as consisting of four main constructs that influence the behavioral intentions of future use: perceived ease of use, perceived usefulness, external variables (a group of constructs), and attitudes toward future use. Perceived usefulness is defined as the degree to which a person believes that using a particular system would improve his or her work efficiency, while perceived ease of use relates to the degree to which a person believes that the use of a particular system would be effortless (Davis, 1993).

The model TAM has been continuously studied and expanded. Among the models, a well known and widely used extended version is TAM 2 (Venkatesh \& Davis, 2000; Venkatesh, 2000). Venkatesh et al. (2003) proposed a unified model called the unified theory of acceptance and use of technology (UTAUT), as well. UTUAT states that "Performance Expectancy which is an extension of Usefulness from TAM, Effort Expectancy which is an extension of Ease of Use from TAM, Social Influence and Facilitating Conditions are determinants of Behavioral Intention or Use Behavior, and that Gender, Age, Experience and Voluntariness of use have moderating effects on the acceptance of IT” (Terzis et al., 2012). A TAM 3 has also been proposed in the context of e-commerce with an inclusion of the effects of trust and perceived risk on system use (Venkatesh \& Bala, 2008).

\section{External factors in TAM}

In the past, TAM was expanded to include several external variables; researches that were based on TAM and were analyzing different aspects of acceptance of statistical software and/or quantitative methods by students included different external technological, social, psychological, and individual and behavioral factors. Researchers who studied the use of the SPSS statistical support program have expanded the TAM model to also include components such as computer attitude, statistics anxiety, statistical software self-efficacy, statistics learning self-efficacy, statistics learning value, and satisfaction with achievements (Brezavšček et al., 2014; Hsu et al., 2009), whereby they have tied these to two key components of the TAM model: the perceived usefulness and the perceived ease of use of SPSS.

Šebjan and Tominc (2015) used the TAM model for research related to the applicability of statistical software support (SPSS program) for economics and business students. The purpose of their research was to test the importance of two external constructs, namely, pedagogical support and compliance with the study needs. Research revealed that the pedagogical support of teachers significantly contributes to the perceived ease of use of SPSS. Specifically, their findings showed that teacher support has a positive and important influence on the perceived ease of use of SPSS and a positive but insignificant effect on the perceived usefulness of the software. Other researchers have reported similar findings (e.g., Lai et al., 2012). Therefore, we assumed that a comparable relationship applies to modeling intentions about the future use of quantitative methods.

It was also found (Šebjan \& Tominc, 2015) that there is a link between the perceived alignment with the field of study, the use of SPSS, and future intention to use SPSS. In other words, the perceived value of SPSS usage within one's study positively affects his/her perceived usefulness of SPSS and the perceived intention of using the software in the future (cf. Emmioğlu \& Capa-Aydin, 2012).

Anxiety can also affect the ability to acquire knowledge and skills in statistics (Hsu et al., 2009; Macher et al., 2012); thus, it is possible that this variable impacts the behavioral intention to use statistics in the future. Anxiety is an undefined experience of endangerment, discomfort, or disturbance that develops out of fear and anxiety, not stemming from an existing but rather anticipated situation. It is a generalized emotional state arising from a subjective problem (Marjanovič Umek et al., 2004).

Individual personal characteristics (more widely described as "personal-level characteristics") have been identified as important antecedents of certain behavioral intentions as well (Krueger et al., 1993; Yousafzai et al., 2007; Linan \& Alain, 2015).

\section{Research Model and Hypotheses}

Our research model is based on the results of previous researches utilizing the TAM model and its extensions, which are described in the previous chapter. As already mentioned, the aim of this paper is not to test dependencies among constructs of extended TAM but to study the relationships among multidimensional variables/constructs 
included into the research model: perceived ease of use of quantitative methods, perceived usefulness of quantitative methods, perceived attitudes toward quantitative methods, and behavioral intentions to use quantitative methods in the future. Based on the research results and arguments, as presented in the literature review, the external variables that are also included into our model are (a) pedagogical support in the study process; (b) perceived alignment of statistical methods with the level of study; (c) statistics anxiety and personal characteristics of individuals; and three variables for personal characteristics, namely (d) ambition and innovativeness; (e) engagement and motivation; and (f) research orientation and analytical thinking.

The research model with the relationships among multidimensional variables is summarized in Figure 1.

Hypotheses of the model are formed with the purpose to test relationship among multidimensional variables:

H1: The correlation between perceived pedagogical support and perceived usefulness of quantitative methods is significant and positive.

H2: The correlation between perceived pedagogical support and the perceived ease of use of quantitative methods is significant and positive.

H3: The correlation between perceived alignment of quantitative methods with the demands of the study program and perceived usefulness of quantitative methods is significant and positive.

H4: The correlation between perceived alignment of quantitative methods with the demands of study program and the perceived ease of use of quantitative methods is significant and positive.

H5: The correlation between statistics anxiety and the perceived usefulness of quantitative methods is significant and negative.
H6: The correlation between statistics anxiety and the perceived ease of use of quantitative methods is significant and negative.

H7,i: The correlation between $i$-th personal characteristics and the perceived usefulness of quantitative methods is significant and positive; $i=1,2,3$.

H8,i: The correlation between $i$-th personal characteristics and the perceived ease of use of quantitative methods is significant and positive; $i=1,2,3$.

H9: The correlation between perceived ease of use of quantitative methods and their perceived usefulness is significant and positive.

H10: The correlation between usefulness of quantitative methods and students' attitudes towards them is significant and positive.

H11: The correlation between perceived ease of use of quantitative methods and and students' attitudes towards them is significant and positive.

H12: The correlation between usefulness of quantitative methods and students' intentions to use them in the future is significant and positive.

H13: The correlation between students' attitudes towards quantitative methods and students' intentions to use them in the future is significant and positive.

\section{Methodology and Data}

The survey was conducted among students (full- and parttime) of the master cycle study program Economics and Business at University of Maribor, Faculty of Economics and Business, in January 2017 ( $n=101)$.

All variables included in the model presented by Figure 1 are multidimensional variables/constructs. A questionnaire

\section{Figure 1. Research Model}

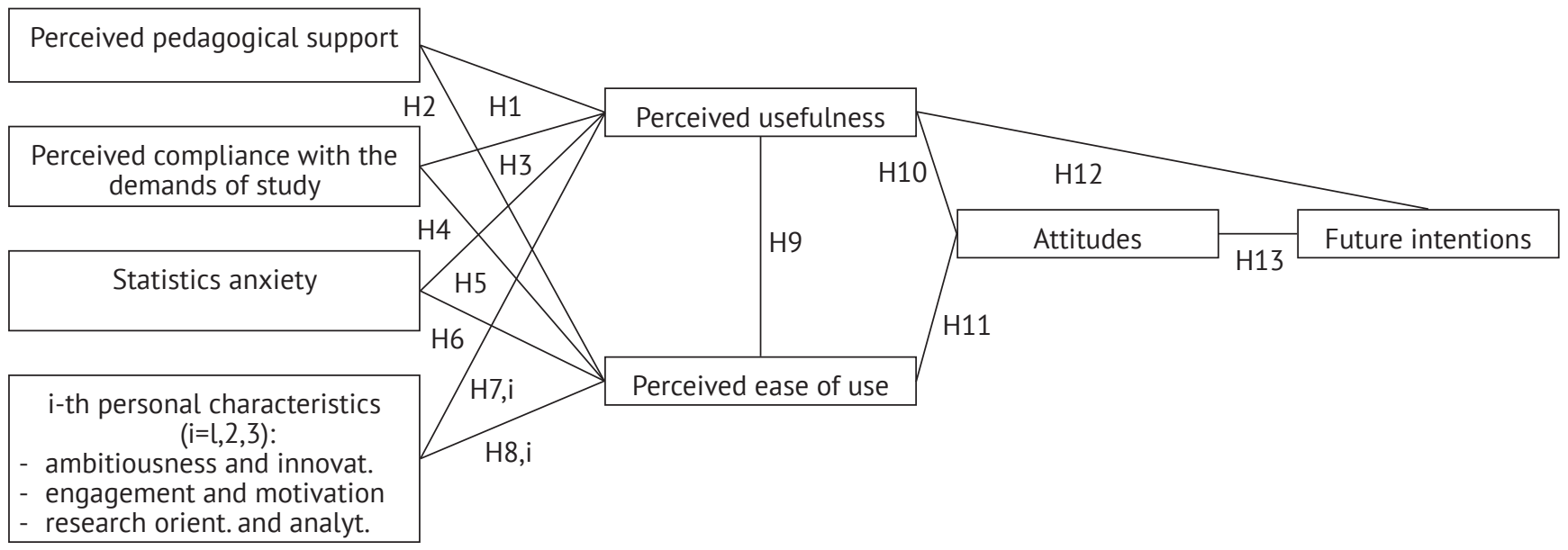

(Source: Authors) 
for measuring multidimensional variables of the model was employed. Items of the constructs' perceived ease of use, perceived usefulness of statistical methods, attitudes toward statistical methods, and intentions to use statistical methods in the future were formed based on Davis's prior studies (Davis et al., 1989), with slight wording modifications made for studying quantitative methods (cf. Park, 2009; Letchumanan \& Muniandy, 2013; Šebjan \& Tominc, 2015). Items of constructs referring to the pedagogical support, statistics anxiety, perceived alignment of quantitative methods with the demands of study and personal characteristics were included in the paper based on Arthur and Yuet Wong (2000); Pierce, Stacey, and Barkatsas (2007); Ameen and Loeffler-Cobia (2010); Vos, van der Meijden, and Denessen (2011); and Nikou and Economides (2016). In the questionnaire, each multidimensional variable was expressed by several statements/items, i.e., students assessed the level of agreement with each statement, from 1 (completely do not agree) to 5 (completely agree).

To establish the structure of the multidimensional variables/ constructs of the research model, factor analysis was used. Bartlett's test of sphericity (BTS), applying the 0.05 significance level and Kaiser-Meyer-Olkin statistics (KMO), applying the treshold $>0.7$ (Field, 2009), were calculated. In the case of more than one factor, a simpler factor structure was obtained using the principal component analysis (PCA) and the Varimax rotation. The criteria that factor loadings of each variable must exceed 0.5 were used to guarantee the reliability and validity of the questionnaire scales (Nunnally, 1978).

Correlation analysis was used to test hypotheses regarding the relationships among multidimensional variables, using the 0.05 significance level.
Structure of the sample is presented in Table 1. Respondents averaged 23.79 years old with $27.7 \%$ of students being male and $72.3 \%$ being female.

Table 1. Structure of the Sample Regarding Age and Gender

\begin{tabular}{|c|c|c|}
\hline \multicolumn{2}{|c|}{ Sample Structure } & \multirow{2}{*}{$\begin{array}{l}f \% \\
27.7 \\
72.3 \\
\end{array}$} \\
\hline Gender & $\begin{array}{l}\text { Male } \\
\text { Female }\end{array}$ & \\
\hline Age & $\begin{array}{l}21-22 \text { years } \\
23-24 \text { years } \\
25-26 \text { years } \\
27-28 \text { years } \\
29 \text { and older }\end{array}$ & $\begin{array}{r}29.7 \\
49.5 \\
12.8 \\
3.0 \\
5.0\end{array}$ \\
\hline
\end{tabular}

\section{Results}

In the first stage of the analysis, the factor analysis was used to obtain the multidimensional variables of the model. Results of the factor analysis are presented in Table 2, where, for all constructs of the research, single factor solutions were obtained, except for the $i$-th personal characteristics, $(i=$ $1,2,3)$ of students, where the two factors solutions were obtained.

Cronbach's alpha coefficients confirm the reliability of the measurement scales for each construct, while KMO statistics and the significance of Bartlett's test for each multidimensional construct confirms that using factor analysis is justified.

Multidimensional variables, i.e., factors obtained, explain the high percentage of the variance of original variables

Table 2. Results of the Factor Analysis for Multidimensional Variables of the Research Model

\begin{tabular}{|c|c|c|c|c|}
\hline Constructs of the research model & Cronbach's Alpha & $\%$ of Variance Explained & KMO & Bartletts Test X2 / Sig. \\
\hline Perceived usefulness of quantitative methods & 0.92 & 77.725 & 0.856 & $412.902 /<0.01$ \\
\hline Perceived ease of use of quantitative methods & 0.86 & 72.657 & 0.757 & $214.728 /<0.01$ \\
\hline Attitude toward quantitative methods & 0.94 & 86.582 & 0.859 & $397.076 /<0.01$ \\
\hline Future intention to use quantitative methods & 0.92 & 81.191 & 0.848 & $305.664 /<0.01$ \\
\hline Perceived pedagogical support & 0.83 & 72.358 & 0.753 & $224.384 /<0.01$ \\
\hline Perceived alignment with study & 0.86 & 79.306 & 0.723 & $149.201 /<0.01$ \\
\hline Statistics anxiety & 0.91 & 79.983 & 0.766 & $342.131 /<0.01$ \\
\hline \multicolumn{5}{|l|}{ Personal characteristics } \\
\hline Ambition & \multirow{2}{*}{0.85} & \multirow{2}{*}{69.767} & \multirow{2}{*}{0.809} & \multirow{2}{*}{$327.828 /<0.01$} \\
\hline Innovativeness & & & & \\
\hline Engagement & \multirow{2}{*}{0.877} & \multirow{2}{*}{64.603} & \multirow{2}{*}{0.839} & \multirow{2}{*}{$476.981 /<0.01$} \\
\hline Motivation & & & & \\
\hline Research orientation & \multirow{2}{*}{0.752} & \multirow{2}{*}{62.736} & \multirow{2}{*}{0.739} & \multirow{2}{*}{$196.559 /<0.01$} \\
\hline Analytical thinking & & & & \\
\hline
\end{tabular}


(items in the questionnaire); for all factors, the percentage of variances explained is higher than $60 \%$.

In the second stage of research hypotheses, $\mathrm{H} 1-\mathrm{H} 13$ were tested.

Table 3. Results for Hypotheses Testing

\begin{tabular}{ll} 
Hypotheses & Correlation Coefficients \\
\hline $\begin{array}{l}\text { H1: Perceived pedagogical } \\
\text { support; Perceived usefulness }\end{array}$ & $0.332^{* *}$ \\
\hline $\begin{array}{l}\text { H2: Perceived pedagogical } \\
\text { support; Perceived ease of use }\end{array}$ & $0.290^{* *}$ \\
\hline $\begin{array}{l}\text { H3: Perceived alignment with } \\
\text { study; Perceived usefulness }\end{array}$ & $0.414^{* *}$ \\
\hline $\begin{array}{l}\text { H4: Perceived alignment with } \\
\text { study; Perceived ease of use }\end{array}$ & $0.625^{* *}$ \\
\hline $\begin{array}{l}\text { H5: Statistics anxiety; } \\
\text { Perceived usefulness }\end{array}$ & $-0.429^{* *}$ \\
\hline $\begin{array}{l}\text { H6: Statistics anxiety; } \\
\text { Perceived ease of use }\end{array}$ & $-0.338^{* *}$ \\
\hline $\begin{array}{l}\text { H7,1: Ambition; Perceived usefulness } \\
\text { Innovativeness; }\end{array}$ & 0.032 \\
$\begin{array}{ll}\text { Perceived usefulness } \\
\text { H7,2: Engagement; }\end{array}$ & -0.008 \\
$\begin{array}{l}\text { Perceived usefulness } \\
\text { Motivation; Perceived usefulness }\end{array}$ & 0.172 \\
\hline $\begin{array}{l}\text { H7,3: Analytical thinking; } \\
\text { Perceived usefulness } \\
\text { Research orientation; }\end{array}$ & $0.205^{*}$ \\
$\begin{array}{l}\text { Perceived usefulness } \\
\text { H8,1: Ambition; Perceived ease of use } \\
\text { Innovativeness; }\end{array}$ & $0.489^{* *}$ \\
\hline $\begin{array}{l}\text { Perceived ease of use } \\
\text { H8,2: Engagement; }\end{array}$ & 0.440 \\
\hline $\begin{array}{l}\text { Perceived ease of use } \\
\text { Perceivedivation; Perceived ease of use }\end{array}$ & -0.001 \\
\hline $\begin{array}{l}\text { H9: Perceived ease of use; } \\
\text { Perceived usefulness }\end{array}$ & 0.105 \\
\hline $\begin{array}{l}\text { H10: Perceived usefulness; Attitudes } \\
\text { Perceived ease of use }\end{array}$ & 0.150 \\
\hline
\end{tabular}

*Significant at 0.05 level; **Significant at 0.01 level.

Several statistically significant correlations were found. Perceived pedagogical support is positively related to perceived ease of use and perceived usefulness of quantitative methods, thus confirming $\mathrm{H} 1$ and $\mathrm{H} 2$. The same is true when students perceive quantitative methods as aligned with their study program's content and objectives, thus confirming H3 and $\mathrm{H} 4$.
Statistics anxiety is significantly negatively related to perceived ease of use and usefulness of quantitative methods, thus confirming $\mathrm{H} 5$ and $\mathrm{H} 6$, as well.

Among students' personal characteristics, the motivation of students was significantly and positively related to perceived usefulness of quantitative methods, thus partly confirming H7,1. Analytical thinking was significantly and positively related to the perceived ease of use of quantitative methods, as expected, thus partly confirming H8,3. Other relationships between personal characteristics and perceived ease of use, as well as with the perceived usefulness of quantitative methods, are not significant. Hypotheses H7,2; H7,3; H8,1; and H8,2 were rejected.

Students who perceive quantitative methods as easy to use generally perceive that quantitative methods are useful as well. Perceived ease of use and perceived usefulness of quantitative methods are significantly and positively related to positive attitudes toward them. Those with more positive attitudes toward quantitative methods, on average, intend to use quantitative methods in the future to a greater extent, which holds true for the perceived usefulness, as well. Therefore, the hypotheses H9, H10, H11, H12 and H13 are confirmed.

\section{Conclusions}

This research brings important information for practitioners, e.g., educators, lecturers, and curricula management teams. Because the importance of statistical knowledge and broader quantitative methods in business and industry has been recognized, graduates have to be equipped with the relevant statistical knowledge before entering the work place. This relevant knowledge and its practical value include the ability to handle massive data sets, where use of statistical software to perform statistical analyses is vital. Efforts to influence positive attitudes may include several counselling activities, encouragement of positive attitudes toward this knowledge by lecturers, case studies, etc. Our research has important implications for higher educational institutions that want to equip their graduates with the competences of conducting quantitative research methods and to enhance their intentions to use these methods in the future.

Teachers of quantitative statistical courses often believe that the majority of students share negative opinions about statistics during and prior to matriculating into the course. Indeed, students often develop negative attitudes toward quantitative methods and statistics and often see the statistical course as an obstacle in their path to graduation. Research results, as listed in the literature, show that a fear 
of statistics is often associated with the students' lack of interest in using statistics and quantitative methods, and their perception that competence in conducting quantitative research is relatively unimportant in employability compared with other competences (e.g., communication skills, critical thinking, etc.) (Chamberlain et al., 2015). Differences exist in the effect sizes of these relationships across different fields and across countries (Emmioğlu \& Capa-Aydin, 2012).

This research suggests that reinforcing the value of quantitative statistical methods for academic programs and in a professional career may be associated with a higher students' intention to use them. It is suggested that the quantitative methods are included into certain academic subjects' research projects where students participate, so that students will have more analytical work with the collection and processing of data, which they therefore learn in the context of their respective study programs.

Researchers have also pointed out that student attitudes toward statistics are often based on students' previous experiences with statistical and mathematical courses (Zhang et al., 2012). Some authors argue that the key factor for negative attitudes toward statistics and for statistical anxiety is the mathematical background of the student. Students, who are worried about a statistics course often feel that that they are not good enough in mathematics and often this harkens back to experiences in primary or secondary education. Teachers should be aware of this problem and should introduce a quantitative statistics course at the beginning of studies and illustrate the difference between quantitative statistics and mathematics (Chamberlain et al., 2015), especially because statistics in management and business studies largely is about information and the interpretation of data rather than mathematical proofs.

Results presented here are preliminary, and several extensions of our research are possible. The next steps in research could be to use structural equation modelling to assess the dependencies among constructs. If the causal effects are confirmed, our results will provide additional insight for teachers of statistical courses.

\section{Acknowledgment}

The authors thank Urban Sebjan, PhD, for his advice in drafting the objectives of this research.

\section{References}

Abdulah, F., Ward, R., \& Ahmed, E. (2016). Investigating the influence of the most commonly used external variables of TAM on students' perceived ease of use (PEOU) and perceived usefulness (PU) of e-portfolios. Computers in Human Behavior, 63, 75-90. https://doi. org/10.1016/j.chb.2016.05.014

Ali, M., B Raja Yaacob, R.A.I., \& Al-Amin B Endut, M.N. (2016). Understanding the academic use of social media: Integration of personality with TAM. Journal of Theoretical \& Applied Information Technology, 90(1), 1-11.

Ajzen, I. (1991). The theory of planned behaviour. Organizational Behavior and Human Decision Processes, 50(2), 179-211. https://doi. org/10.1016/0749-5978(91)90020-T

Antonius, N., Xu, J., \& Gao, X. (2015). Factors influencing the adoption of enterprise social software in Australia. Knowledge-Based Systems, 73, 32-43. https://doi.org/10.1016/j.knosys.2014.09.003

Ameen C., A., Loeffler-Cobia, J., Clawson, E., \& Guevara, M. (2010). Evidence-based practices skills assessment for criminal justice organizations. Washington, DC: National Institute of Corrections.

Arthur, D., \& Wong, F. (2000). The effects of the 'learning by proposing to do' approach on Hong Kong nursing students' research orientation, attitude toward research, knowledge, and research skill. Nurse Education Today, 20(8), 662-671. https://doi.org/10.1054/nedt.2000.0486

Bagozzi, R. P. \& Yi, Y. (1998). On the evaluation of structural equation model. Journal of the Academy of Marketing Science, 16, 74-94. https:// doi.org/10.1007/BF02723327

Biehler, R. (1997). Software for learning and for doing statistics. International Statistical Review, 65(2), 167-189. https://doi. org/10.1111/j.1751-5823.1997.tb00399.x

Bovas, A. (2007). Implementation of statistics in business and industry. Revista Colombiana de Estadistica, 30(1), 1-11.

Brezavšček, A., Šparl, P., \& Žnidaršič, A. (2017). Factors influencing the behavioural intention to use statistical sftware: The perspective of the Slovenian students of social sciences. Eurasia Journal of Mathematics, Scienec and Technology Education, 13(3), 953-986.

Chamberlain J., M., Hillier, J., \& Signoretta, P. (2015). Counting better? An examination of the impact of quantitative method teaching on statistical anxiety and confidence. Active Learning in Higher Education, 16(1), 51-66. https://doi.org/10.1177/1469787414558983

Davis, F. D. (1986). A technology acceptance model for empirically testing new end-user information systems: theory and results. Doctoral dissertation, Sloan School of Management. MIT.

Davis, F.D. (1989). Perceived usefulness, Perceived ease of use and user acceptance of information technology. MIS Quarterly, 13(3), 319-340. https://doi.org/10.2307/249008 
Davis, F. (1993). User acceptance of information technology: System characteristics, user perceptions and behavioral impacts. International Journal of Man-Machine Studies, 38(3), 475-487. https://doi.org/10.1006/imms.1993.1022

Dizon, G. (2016). Measuring Japanese EFL student perceptions of Internet-based tests with the technology acceptance model. The Electronic Journal for English as a Second Language, 2, 1-17.

Emmioğlu, E., \& Capa-Aydin, Y. (2012). Attitudes and achievement in statistics: a meta-analysis study. Statistics Education Research Journal, 11(2), 95-102.

Field, A. (2009). Discovering statistics using SPSS. London: Sage.

Fishbein, M., \& Ajzen, I. (1975). Belief, attitude, intention, and behavior: An introduction to the theory and research. Reading, MA:Addison-Wesley.

Gal, I., \& Ginsburg, L. (1994). The role of beliefs and attitudes in learning statistics: towards an assessment frame-work. Journal of Statistics Education [online], 2(2), http://www.amstat.org/publications/jse/v2n2/gal.html. https://doi.org/10.1080/10691898.1994.11910471

Hsu K., M., Wang S., W., \& Chiu K., K. (2009). Computer attitude, statistics anxiety and self-efficacy on statistical software adoption behavior: An empirical study of online MBA learners. Computers in Human Behavior, 25(2), 412-420. https://doi.org/10.1016/j.chb.2008.10.003

Krueger, F., Norris, A., \& Carsrud, I. (1993). Entrepreneurial intentions: Applying the theory of planned behavior. Entrepreneurship and Regional Development, 5(4), 315-330. https://doi.org/10.1080/08985629300000020

Lai, C., Wang, O., \& Lei, J. (2012). What factors predict undergraduate students' use of technology for learning? A case from Hong Kong. Computers and Education, 59(2), 569-579. https://doi.org/10.1016/j.compedu.2012.03.006

Letchumanan, M., \& Muniandy, B. (2013). Migrating to e-book: A study on perceived usefulness and ease of use. Library Hi Tech News, 30(7), 10-16. https://doi.org/10.1108/LHTN-05-2013-0028

Linan, F., \& Alain F. (2015). A systematic literature review on El: Citation, thematic analyses and research agenda. International Entrepreneurship and Management Journal, 11(4), 907-933. https://doi.org/10.1007/s11365-015-0356-5

Linkedln, (2016). Retreived from: https://blog.linkedin.com/2016/10/20/top-skills-2016-week-of-learning-linkedin.

Linkedln, (2018). Retreived from: https://learning.linkedin.com/blog/top-skills/the-skills-companies-need-most-in-2018--and-the-courses-to-get-t.

Lo S., K., \& Stevenson, M. (1991). Attitudes and perceived usefulness of statistics among health sciences students. International Journal of Mathematical Education in Science and Technology, 22(6) 977-983. https://doi.org/10.1080/0020739910220616

Macher, D., Paechter, M., Papousek, I., \& Ruggeri, K. (2012). Statistics anxiety, trait anxiety, learning behavior, and academic performance. European Journal of Psychology and Education, 27(4), 483-498. https://doi.org/10.1007/s10212-011-0090-5

Marjanovič Umek, L., Zupančič, M., Fekonja, U., Kavčič, T., Svetina, M., Tomazo Ravnik, T., \& Bratanič, B. (2004). Razvojna psihologija. Ljubljana: Znanstvenoraziskovalni inštitut Filozofske fakultete.

Mondejar-Jimenez, J., \& Vargas-Vargas, M. (2010). Determinant factors of attitude towards quantitative subjects: Differences between sexes. Teaching and Teacher Education, 26, 688-693. https://doi.org/10.1016/j.tate.2009.10.004

Murtonen, M., \& Lehtinen, E. (2010). Difficulties experienced by education and sociology students in quantitative methods courses. Studies in Higher Education, 28(2), 171-185. https://doi.org/10.1080/0307507032000058064

Nikou, S., \& Economides, A. (2016). The impact of paper-based, computer-based and mobile-based self-assessment on students' science motivation and achievement. Computers in Human Behavior, 55, 1241-1248. https://doi.org/10.1016/j.chb.2015.09.025

Nunnally, J. C. (1978). Psychometric theory. New York: Mc-Graw-Hill Book Company.

Park S., Y. (2009). An analysis of the technology acceptance model in understanding university students' behavioral intentions to use e-learning. Educational Technology and Society, 12(3), 150-162.

Pierce, R., Stacey, K., \& Barkatsas A., N. (2007). A scale for monitoring students' attitudes to learning mathematics with technology. Computer and Education, 48(2), 285-300. https://doi.org/10.1016/j.compedu.2005.01.006

Sabalic, M. \& Schoener, J. D. (2017). Virtual reality-based technologies in dental medicine: knowledge, attitudes and practice among students and practitioners, technology, knowledge and learning, In print, DOI: 10.1007/s10758-017-9305-4. https://doi.org/10.1007/s10758-017-9305-4

Šebjan, U., \& Tominc, P. (2015). Impact of support of teacher and compatibility with needs of study. Computers in Human Behavior, 53, 354-365. https://doi.org/10.1016/j.chb.2015.07.022

Terzis, V., Moridis, C. N. \& Economides, A. A. (2012). How student's personality traits affect Computer Based Assessment Acceptance: Integrating BFI with CBAAM. Computers in Human Behavior, 28(5), 1985-1996. https://doi.org/10.1016/j.chb.2012.05.019

Venkatesh, V., \& Davis F. D. (1996). A model of the antecedents of perceived ease of use: development and test. Decision Sciences, 3,451-481.

Venkatesh,V., \& Davis, F.D. (2000). A theoretical extension of the technology acceptance model: Four longitudinal field studies. Management Science, 46(2), 186-204, doi:10.1287/mnsc.46.2.186.11926. https://doi.org/10.1287/mnsc.46.2.186.11926

Venkatesh, V. (2000). Determinants of perceived ease of use: Integrating control, intrinsic motivation, and emotion into the technology acceptance model. Information Systems Research, 11(4), 342-365. https://doi.org/10.1287/isre.11.4.342.11872

Venkatesh, V., Morris, M.G., Davis, G. B. \& Davis F. D. (2003). User acceptance of information technology: Toward a unified view. MIS Quarterly, 27-3. https://doi.org/10.2307/30036540

Venkatesh, V. \& Bala, H. (2008). Technology acceptance model 3 and a research agenda on interventions. Decision Sciences, 39(2), $273-315$. https://doi.org/10.1111/j.1540-5915.2008.00192.x

Vos, N., van der Meijden, H., \& Denessen, E. (2011). Effects of constructing versus playing an educational game on student motivation and deep learning strategy use. Computers and Education, 56, 127-137. doi:10.1016/j.compedu.2010.08.013 https://doi.org/10.1016/j. compedu.2010.08.013 
World Economic Forum, (2016). The future of jobs and skills, Executive Summary.

World Economic Forum, (2018). Retreived from: https://www.weforum.org/agenda/2016/01/the-10-skills-you-need-to-thrive-in-thefourth-industrial-revolution/

Yousafzai S., Y., Foxall G., R., \& Pallister J., G. (2007). Technology acceptance: a meta-analysis of the TAM: Part 1. Journal of Modelling in Management, 2(3), 251-280. https://doi.org/10.1108/17465660710834453

Zhang, Y., Shang, L., Wang, R., Zhao, Q., Li, C., Xu, Y., \& Su, H. (2012). Attitudes towards statistics in medical postgraduates: Measuring, evaluating and monitoring. BMC Medical Education, 12(117), 1-8. https://doi.org/10.1186/1472-6920-12-117

\section{Authors}

Polona Tominc, Ph.D., is a full-time Professor in the Department of Quantitative Economic Analysis at the Faculty of Economics and Business, University of Maribor. Her research is focused on statistical methods in economics and business sciences, especially in the field of entrepreneurship, gender differences and behavioural differences between social groups in different fields of management.

Maruša Krajnc is a Master student of Economics and Business Sciences at the Faculty of Economics and Business in Maribor (UM FEB). She bases her work in the fields of accounting, auditing and taxation. In 2015, she completed a professional higher education program in Business Administration at the UM FEB. She currently conducts professional accounting work.

Klavdija Vivod is a Master student of Economics and Business Sciences at the Faculty of Economics and Business in Maribor (UM FEB). She bases her work in the fields of accounting, auditing and taxation. She completed her undergraduate studies at the UM FEB. She is currently engaged in professional work in the field of accounting and finance.

Monty Lynn, Ph.D., is the Caruth Chair of the Owner-Managed Business in the College of Business Administration at Abilene Christian University in Abilene, Texas (USA), where he teaches business and development studies. His recent research interests include market systems development and the assessment of development initiatives. In 1994-1995, he served as a Fulbright scholar with the University of Maribor's Faculty of Economics and Business.

Blaž Frešer obtained his Master's degree in Economics and Business Sciences at the Faculty of Economics and Business in Maribor (UM FEB). Blaž is a junior researcher and assistant in the field of entrepreneurship at the Faculty of Economics and Business, University of Maribor, where he successfully completed his undergraduate and graduate studies in the field of accounting, auditing and taxation. His doctoral studies are focused on the financial aspects of entrepreneurship.

\section{Pričakovane namere študentov glede prihodnje uporabe kvantitativnih metod}

\section{Izvleček}

Spremembe, povezane s pomenom kompetenc diplomantov za delodajalce, in spremembe kompetenc samih so v veliki meri posledica tehnoloških sprememb, digitalizacije in pojava velikih podatkov. Med temi kompetencami postajajo izjemno pomembne sposobnosti opravljanja poslovne in podatkovne analitike, ki temelji na statističnem razmišljanju in podatkovnem rudarjenju. V tem članku proučujemo odnose med več konstrukti, ki so povezani z odnosom študentov ekonomskih in poslovnih ved do kvantitativnih statističnih metod in njihovimi nameni, da jih bodo uporabljali v prihodnosti. Ugotovitve naše raziskave prinašajo pomembne vpoglede za strokovnjake, pedagoge, predavatelje in oblikovalce kurikuluma.

Ključne besede: pričakovane namere študentov, kvantitativne statistične metode 